\title{
SUDDEN SENSORINEURAL HEARING LOSS IN CHILDREN: A LITERATURE REVIEW
}

\author{
Piotr Henryk Skarzynski ${ }^{1,2,3}$, Joanna Rajchel ${ }^{1}$, Henryk Skarzynski ${ }^{1}$ \\ ${ }^{1}$ World Hearing Center, Institute of Physiology and Pathology of Hearing, Warsaw/Kajetany, Poland \\ ${ }^{2}$ Heart Failure and Cardiac Rehabilitation Department, Medical University of Warsaw, Warsaw, Poland \\ ${ }^{3}$ Institute of Sensory Organs, Warsaw/Kajetany, Poland
}

Corresponding author: Piotr Henryk Skarzynski, World Hearing Center, Institute of Physiology and Pathology of Hearing, Mokra 17 Street, 05-830 Nadarzyn, Poland, e-mail: p.skarzynski@ifps.org.pl

\begin{abstract}
Many issues concerning sudden sensorineural hearing loss (SSNHL) remain unresolved. An especially troublesome and uncharted field is SSNHL in children. The aim of the present literature review was to recognize, critically evaluate, and synthesize knowledge on pediatric SSNHL derived from available studies. Articles published between 2000 and 2016 in the English and Polish languages were investigated. Included in the analysis were studies examining children and adolescents $\leq 18$ years or, in the case of comparative studies of children and adults, reports which treated the younger age group as a separate entity. An increase in the attention given to pediatric SSNHL could be observed over the last 16 years. Due to substantial differences in approach found in the analyzed articles, it was impossible to conduct a meta-analysis and provide descriptive statistics. The average age of the investigated children was 12 years. There was no difference in SSNHL prevalence between either gender. Unilateral cases were much more common than bilateral, and no preponderance for left or right ear was noted. The most common factors accompanying SNSHL were tinnitus and vertigo; the most common proposed etiologies were idiopathic and viral infections. There were two main treatment types: steroids (oral, intratympanic, intravenous) and hyperbaric oxygen therapy. Depending on the treatment protocol, the rate of complete recovery ranged from 9 to $57 \%$. The most common positive prognostic factors were mild degrees of hearing loss, occurrence of tinnitus, and early treatment onset, whereas bilateral hearing loss and vertigo were found to be negative prognostic factors.
\end{abstract}

Key words: sudden sensorineural hearing loss $\bullet$ children $\bullet$ literature review

\section{SORDERA SÚBITA EN NIÑOS: REVISIÓN BIBLIOGRÁFICA}

\section{Resumen}

Numerosos aspectos relacionados con la hipoacusia neurosensorial súbita (HNS) en niños siguen siendo poco claros. Este problema concierne sobre todo a los niños. El objetivo de esta revisión bibliográfica es una evaluación critica, así como un intento de síntesis de las contribuciones científicas contemporáneas sobre HNS en esta categoría de edad. Se han analizado artículos científicos en polaco y español del periodo 2000-2016. En la revisión se han incluido los trabajos en los cuales se presentaron los resultados de estudios en niños y adolescentes menores de 18 años, así como artículos comparativos que analizan los resultados infantiles tratando los niños como un grupo de estudio aparte. Recientemente se ha podido observar cada vez más interés en el tema de HNS en los pacientes más pequeños. Por las diferencias significantes entre metodologías y métodos de evaluación aplicados por varios autores, ha sido imposible realizar el metaanálisis. Por este motivo, se ha optado por elegir la estadística descriptiva. La media de edad de los niños que se presentaron con HSN fue de 12 años. No se observaron diferencias en cuanto a la incidencia de HNS dependiendo del género. Fueron mucho más frecuentes los casos de HNS unilateral que de la bilateral, sin embargo no se observaron más casos del oído izquierdo o derecho. Los síntomas más frecuentes coexistentes con la pérdida auditiva eran los tinnitus y el vértigo. Como etiologías más comunes se indicaron los casos idiopáticos y las infecciones virales. En los artículos analizados aparecían dos principales tipos de tratamiento: el esteroideo (vía oral, intratimpánica, intravenosa) y el tratamiento en cámaras hiperbáricas. Dependiendo del plan de tratamiento aplicado, se observaba recuperación total de los umbrales auditivos en 9-57\% de los niños. Como factores pronósticos positivos se han propuesto: un grado más leve de pérdida auditiva, la coexistencia de tinnitus y la introducción temprana del tratamiento, en cambio como factores pronósticos negativos: la perdida auditiva bilateral y el vértigo.

Palabras clave: sordera neurosensorial súbita • niños • revisión bibliográfica 


\section{ВНЕЗАПНАЯ ГЛУХОТА У ДЕТЕЙ - ОБЗОР ЛИТЕРАТУРЫ}

\section{Изложение}

Большое количество вопросов, касающихся внезапной нейросенсорной тугоухости продолжает оставаться неясным. Данная проблема касается в частности детей. Целью настоящего обзора литературы является критическая оценка и попытка синтеза современных научных публикаций на тему внезапной нейросенсорной тугоухости в данной возрастной группе. Были проанализированы научные статьи, написанные в 2000-2016 гг. на польском и английском языке. В обзор были включены работы, в которых представлены результаты исследований детей и молодежи в возрасте ниже 18 лет, а также сравнительные статьи, анализирующие результаты детей как отдельной исследуемой группы. В последние годы наблюется растущий интерес к теме внезапной нейросенсорной тугоухости у самых маленьких пациентов. В связи со значительными различиями в методологии и способах оценки результатов, использующихся разными авторами, метаанализ был невозможен. По этой причине было принято решение о выборе описательной статистики. Возраст детей, обращавшихся к врачу с внезапной нейросенсорной тугоухостью, составлял в среднем 12 лет. Не была обнаружена разница в частоте появления внезапной нейросенсорной тугоухости у детей разного пола. Случаи односторонней внезапной нейросенсорной тугоухости имели место значительно чаще, нежели двусторонней, однако нет различий в отношении частоты случаев потери слуха в правом или левом ухе. Самыми частыми симптомами, сопутствующими потере слуха, являлись шум в ушах и головокружения. В качестве наиболее распространённой этиологии указаны идиопатические случаи и вирусные инфекции. В анализируемых статьях представлены два основных вида лечения: стероидное (пероральное, внутрибарабанное и внутривенное) и гипербарическая оксигенация. В зависимости от использованного протокола лечения полное восстановление порогов слышимости имело место у 9-57\% детей. В качестве положительных прогностических факторов предложены более мягкая степень потери слуха, сопутствующий шум в ушах и ранее внедрение лечения, в то время как отрицательными прогностическими факторами считаются двусторонняя потеря слуха и головокружения.

Ключевые слова: внезапная нейросенсорная тугоухость • дети • обзор литературы

\section{NAGŁY NIEDOSŁUCH ODBIORCZY U DZIECI - PRZEGLĄD LITERATURY}

\section{Streszczenie}

Wiele kwestii dotyczących nagłego niedosłuchu czuciowo-nerwowego (NNCN) pozostaje nadal niejasnych. Problem ten dotyczy w szczególności dzieci. Celem niniejszego przeglądu literatury jest krytyczna ocena oraz próba dokonania syntezy współczesnych doniesień naukowych na temat NNCN w tej grupie wiekowej. Analizie poddane zostały artykuły naukowe z lat 20002016 r. w języku polskim oraz angielskim. Do przeglądu włączono prace, w których przedstawiono wyniki badań nad dziećmi i młodzieżą poniżej 18 r.ż., jak również artykuły porównawcze analizujące wyniki dzieci jako osobną grupę badawczą. W ostatnich latach można zaobserwować rosnące zainteresowanie tematem NNCN u najmłodszych pacjentów. Ze względu na znaczne różnice w metodologii i sposobach ewaluacji wyników stosowanych przez różnych autorów, niemożliwe było przeprowadzenie metaanalizy. Wiek dzieci zgłaszających się z NNCN wynosił średnio 12 lat. Nie stwierdzono różnic płci w częstości występowania NNCN. Jednostronne przypadki NNCN były znacznie częstsze niż obustronne, nie występowała jednak różnica w przewadze przypadków ubytku w prawym lub lewym uchu. Najczęstszymi objawami współwystępującymi z ubytkiem słuchu były szumy uszne oraz zawroty głowy. Jako najbardziej powszechne etiologie wskazano przypadki idiopatyczne oraz infekcje wirusowe. W analizowanych artykułach występowały dwa podstawowe rodzaje leczenia: sterydowe (ustne, dobębenkowe oraz dożylne) oraz leczenie komorą hiperbaryczną. W zależności od zastosowanego protokołu leczenia, całkowity powrót progów słyszenia występował u 9 do 57\% dzieci. Jako pozytywne czynniki prognostyczne zaproponowano łagodniejszy stopień ubytku słuchu, współwystępowanie szumów usznych oraz wczesne wdrożenie leczenia, natomiast jako negatywne czynniki prognostyczne obustronny ubytek słuchu oraz zawroty głowy.

Słowa kluczowe: nagła głuchota czuciowo-nerwowa $\bullet$ dzieci • przegląd literatury

\section{Background}

Although many articles concerning sudden sensorineural hearing loss (SSNHL) exist in the literature, it still remains a condition with more questions than answers. Many issues remain unresolved: establishing an evidence-based definition of the disease and determining its etiology, choosing the most effective management protocol, and evaluating treatment outcomes [1]. An especially troublesome and uncharted field is SSNHL in children. It is widely accepted that hearing impairment in a child may lead to significant social [2], behavioral [3], and mental [4-7] problems and, consequently, constitute a burden for the whole family. Therefore, in the case of acute hearing loss, special efforts should be undertaken to prevent children from suffering permanent hearing loss by providing the best possible treatment options.

Currently applicable guidelines and review articles are based on studies which cover, almost exclusively, adult 
patients [1,8-11]. Even the most recent articles which discuss SSHL in children, along with other possible causes of acquired hearing loss, contain data derived mostly from adults [12]. The aim of this pediatric SSNHL review is to recognize, critically evaluate, and synthesize knowledge derived from the literature. By doing this, our aim is to ensure a better understanding of SSNHL in children and initiate discussions concerning this neglected problem. In this review, special emphasis is placed on:

- SSNHL definition,

- sociodemographic data and accompanying symptoms,

- the course of diagnosis,

- SSNHL etiology,

- hearing loss and audiogram type classifications,

- treatment types,

- the effectiveness of methods selected for treatment,

- treatment outcomes,

- follow-up schedules,

- negative and positive prognostic factors.

\section{Material and methods}

Due to the paucity of literature concerning pediatric SSN$\mathrm{HL}$, we decided to include in the review all types of articles, the only exclusion being case reports, which we consider have methodological limitations such as an inability to generalize the findings [13]. Articles reported in English and Polish were investigated. We included in the analysis studies carried out between 2000 and 2016 which gave information about both previous and most recent findings. Two main interventions were of interest: steroids (systemic, intratympanic, and intravenous) and hyperbaric oxygen therapy, which also feature in the adult literature.

According to The United Nation Convention on the Rights of the Child, "a child means every human being below the age of eighteen years unless, under the law applicable to the child, majority is attained earlier" [14]. However, different authors use various age criteria while evaluating SSNHL "in children" around the world. Not to miss any important data, studies with individual exceptions of patients over 18 years of age were also included in the analysis. In case of comparative studies between children and adults, articles which treated children under 18 years of age as a separate group were admitted. Key words selected for each search were, in English, "sudden deafness", "sudden sensorineural hearing loss", and "children"; and, in Polish, "nagła głuchota", "nagły niedosłuch czuciowonerwowy", and "dzieci".

The following electronic databases known for their medical and scientific value were used to find relevant literature: PubMed, ScienceDirect, Embase, Medline, Web of Science, and Google Scholar. Reference lists of every matching article found were scanned to avoid losing any important item. Articles eligible for review were selected first by screening the title. Then, every abstract was carefully studied to confirm the eligibility criteria. Construction of a database of all articles admitted for full-text screening was done with the help of Zotero, an open-source reference management software used to build bibliographies. Duplicates were removed.
Using the English key words, a total of 2963 articles were found: PubMed (482), ScienceDirect (2006), Embase (233), Medline (28), and Web of Science (139). When we performed a second search using Polish key words in Google Scholar, there were an additional 245 articles. After careful examination of titles and abstracts, 61 articles were accepted for further examination, and after removal of duplicates, there were 13 articles on pediatric SSNHL, 12 in English and 1 in Polish, which were admitted for full-text analysis

\section{Results}

Table 1 lists the 13 publications in chronological order, giving details of authors, publication year, language, observation time, the number of investigated children, and the study's country of origin. A growing interest in pediatric SSNHL can be observed over the last 16 years. The SSNHL studies were carried out in South Korea [15,16], Turkey [17,18], France [19], Germany [20], Greece [21], Poland [22], USA [23], Serbia [24], Israel [25], and China [26]. Due to substantial differences in scientific approaches found in the analyzed articles, it was not possible to conduct a meta-analysis. The number of children in each study ranged from 12 to 136, providing 526 examined cases in total. All articles used a review of retrospective medical records. Ten articles considered SSNHL only in pediatric patients [17-23,25-27], two articles [15,16] were comparative studies between adults and children, and one article was a review presenting additional original data on pediatric SSNHL etiology and recovery [24].

\section{SSNHL definition}

The most common definition of SSNHL encountered in the pediatric literature covers three main components: the time of occurrence, the magnitude of hearing loss, and the number of affected frequencies. The majority of authors (in 11 of 13 articles) defined SSNHL as a hearing loss $\geq 30$ $\mathrm{dB}$ HL, developing within 3 days, and affecting at least 3 contiguous frequencies [15,17-19,21-27]. However, some considerable discrepancies between studies were identified. In three articles the term "sudden hearing loss" (SHL) $[19,21,24]$ was used to describe the above-mentioned criteria and $\mathrm{Na}$ et al. [15] utilized the term "sudden deafness". Chung et al. [16] did not specify the time-frame for developing SSNHL; Inci et al. [17] and Kizilay and Koca [18] limited their audiological description of SSNHL exclusively to idiopathic cases. The definition of SSNHL was completely passed over in the study of Chen et al. [20].

There is still no standard definition of SSNHL. According to the Clinical Practice Guideline developed by the American Academy of Otolaryngology - Head and Neck Surgery (AAOHNS), SSNHL is a subtype of sudden hearing loss (SHL). Whereas SHL is a broad concept characterized by acute onset (within 3 days), resulting in a subjective feeling of hearing deterioration in one or both ears, the definition of SSNHL is based on more detailed audiological criteria: i.e., a hearing level impairment of $\geq 30 \mathrm{~dB}$ HL compared to the non-affected ear, involving at least 3 contiguous frequencies, and originating from an anomaly of the cochlea, auditory nerve, or structures in the higher auditory pathway. In the Clinical Practice Guideline, the authors favor one more subset of SSNHL 
Table 1. Articles discussing pediatric SSNHL in order of year of publication

\begin{tabular}{|c|c|c|c|c|c|c|}
\hline No. & Authors & Publication year & Language & Country & $\begin{array}{c}\text { Observation } \\
\text { time }\end{array}$ & $\begin{array}{c}\text { Material } \\
\text { (number of children) }\end{array}$ \\
\hline 1 & Roman et al. & 2001 & English & France & 1990-99 & 12 \\
\hline 2 & Chen et al. & 2005 & English & Germany & 2000-03 & 14 \\
\hline 3 & Psarommatis et al. & 2009 & English & Greece & $2002-07$ & 48 \\
\hline 4 & Narożny et al. & 2010 & Polish & Poland & $2004-08$ & 17 \\
\hline 5 & Inci et al. & 2011 & English & Turkey & 2000-08 & 43 \\
\hline 6 & Tarshish et al. & 2013 & English & USA & $2007-12$ & 20 \\
\hline 7 & $\mathrm{Na}$ et al. & 2014 & English & South Korea & $2003-12$ & 87 \\
\hline 8 & $\begin{array}{l}\text { Jecmenica and } \\
\text { Bajec-Opancina }\end{array}$ & 2014 & English & Serbia & $2000-13$ & 59 \\
\hline 9 & Chung et al. & 2015 & English & South Korea & $2007-13$ & 37 \\
\hline 10 & Pitaro et al. & 2016 & English & Israel & $2003-14$ & 19 \\
\hline 11 & Dedhia and Chi & 2016 & English & USA & $2000-13$ & 20 \\
\hline 12 & Li et al. & 2016 & English & China & $2008-15$ & 136 \\
\hline 13 & Kizilay and Koca & 2016 & English & Turkey & 2004-15 & 14 \\
\hline
\end{tabular}

Table 2. Data, in order of publication year, on children's ages (in years), gender, laterality of SSNHL, and selected accompanying factors (number of cases) identified in the pediatric SSNHL literature

\begin{tabular}{|c|c|c|c|c|c|c|c|c|}
\hline \multirow{2}{*}{ Authors } & \multirow{2}{*}{$\begin{array}{l}\text { Age } \\
\text { range }\end{array}$} & \multirow{2}{*}{$\begin{array}{l}\text { Mean } \\
\text { age }\end{array}$} & \multicolumn{2}{|c|}{ Gender } & \multicolumn{2}{|c|}{ Laterality of SSNHL } & \multicolumn{2}{|c|}{ Other symptoms } \\
\hline & & & male & female & unilateral & bilateral & tinnitus & vertigo \\
\hline Roman et al. & $3-14.5$ & 9.5 & 6 & 6 & NP & NP & 4 & 1 \\
\hline Chen et al. & $9-18$ & 15 & 9 & 5 & 14 & 0 & 6 & NP \\
\hline Psarommatis et al. & $4-14$ & 9.05 & 19 & 29 & NP & NP & NP & NP \\
\hline Narożny et al. & $8-17$ & 14.7 & NP & NP & NP & NP & NP & NP \\
\hline Inci et al. & $5-15$ & 11.14 & 30 & 13 & 36 & 7 & 22 & NP \\
\hline Tarshish et al. & $0-24$ & 11.41 & 12 & 8 & 11 & 9 & 9 & 9 \\
\hline Na et al. & $0-15$ & 12.5 & 48 & 39 & 80 & 7 & NP & NP \\
\hline Jecmenica et al. & NP & NP & NP & NP & 16 & 32 & NP & NP \\
\hline Chung et al. & $6-18$ & 14.3 & 19 & 18 & 37 & 0 & 16 & 6 \\
\hline Pitaro et al. & $7-18$ & 14 & 9 & 10 & 18 & 1 & 14 & 3 \\
\hline Dedhia and Chi & $1-18$ & 11.25 & 10 & 10 & 12 & 8 & 11 & 4 \\
\hline Li et al. & $2-18$ & 11.7 & NP & NP & 106 & 15 & NP & NP \\
\hline Kizilay and Koca & $6-15$ & 10.1 & 5 & 9 & 12 & 2 & 3 & 2 \\
\hline Total & $0-24$ & 12.05 & 167 & 147 & 342 & 81 & 85 & 25 \\
\hline
\end{tabular}

NP - data not provided.

- idiopathic sudden sensorineural hearing loss (ISSNHL), which is of unknown cause despite thorough examination [1]. The audiometric description of SSNHL used in most studies examined in this literature review was consistent with the definition utilized by AAOHNS. However, different names for the same phenomenon were given by different authors. Also, the definition of the investigated condition was not always provided. Flexibility or interchangeable use of the term "sudden deafness", "acute hearing loss", "sudden sensorineural hearing loss", etc., or even avoiding its definition, can often lead to substantial misunderstanding, such as in the case of differentiating between non-organic (also called psychogenic) vs. organic hearing loss and sudden sensorineural vs. mixed or conductive hearing loss. Establishing standard, clear, and transparent definitions of different types of hearing loss would benefit many areas of research. The definition of SSNHL is a core concept on which a whole study depends. Use of standard terms allows homogenous groups of patients to be created, meta-analysis of findings from 
different, yet comparable studies, to be made, and desired, specific-theme articles to be identified.

\section{Sociodemographic data and accompanying symptoms}

Most authors reported the incidence of SSNHL as 5-20 per 100000 overall [17-20,22,27], making no distinction between adults and children. Such data was also provided in the Clinical Practice Guideline on Sudden Hearing Loss developed in 2012 by the American Academy of Otolaryngology - Head and Neck Surgery [1]. Studies published in the last two years $[16,25,26]$ mainly cite the Alexander and Harris results [28], where the incidence of SSNHL was established as 27/100 000 in general, and showed that morbidity increased with age from 11/100 000 (children under 18 years old) to 77/100 000 (people over 65). Table 2 shows a summary of age, gender, laterality of SSNHL, and selected accompanying factors derived from the pediatric literature.

\section{Diagnostic process}

The main part of the diagnostic protocol was pure-tone audiometry (PTA), used in almost every article under review. A general diagnostic protocol concerning pediatric SSNHL was proposed by Jecmenica and Bajec-Opancina (although it was not specified whether the authors used this protocol in their own study). The protocol included medical history taking, otorhinolaryngology examination with otomicroscopy, establishment of hearing threshold, subjective or objective audiometry, vestibular testing, examination by an ophthalmologist and pediatrician, specific laboratory analysis (serological testing for rubella, parotitis, CMV, herpes simplex virus, syphilis, toxoplasma gondi, hormone test of thyroid function, urine analysis), genetic counselling, and neuroradiological examination with CT and MRI. Unfortunately, no protocol referral was provided, so it is uncertain if the data was based on the creator's own experience or other sources.

Different diagnostic protocols were used in the articles under review here, and discrepancies were apparent in studies focused on either idiopathic or specific etiology cases. For example, Dedhia and Chi [27] presented the viewpoint that it could be potentially beneficial to obtain both CT and MRI scans in children suspected of SSNHL. The authors stated that there are some anomalies which can be detected exclusively with CT or MRI, such as with two patients who had an enlarged vestibular aqueduct on CT scan but no correlating enlarged endolymphatic sac on MRI. Such an approach was not used in other studies under review. Additionally, in a study conducted by Li et al. [26], some laboratory findings (such as level of WHC, platelet, homocysteine, alkaline phosphatase, positive CMV IgG antibody, fibrinogen, and some immunologic indicators) were closely related to pediatric SSNHL. The authors state that their results support the view that several important clinical indicators can help in the diagnosis and treatment of SSNHL. Also, the recent findings by Lee et al. [29] on the role of neutrophil-to-lymphocyte ratio (NLR) suggest that NLR might be a possible indicator of pediatric SSNHL. Regrettably, omitting the explanation for why certain examinations of individual children are chosen creates a large research gap. Selective investigations can potentially lead to bias in reporting outcomes.

\section{Eligibility criteria}

In the majority of articles, inclusion and exclusion criteria were rarely identified [21,23-25]. The main focus was placed on children's ages, consistency with the audiological definition of SSNHL confirmed by PTA, and exclusion of outer and middle ear diseases [15,17,18,22,27]. In some articles, a limited time between SSNHL onset and the beginning of treatment was also considered an eligibility criterion, such as 8 days in the study by Roman et al. [19], 10 days by Narożny et al. [22], or 14 days by Chen et al. [20]. The explanation for the chosen timeframe was not provided. Laboratory and radiological findings were also used to select material $[16,19,20]$; in one study, they were also accompanied by genetic and hearing screening tests [26]. The most accurate eligibility criteria were found in Roman et al. [19] and Li et al. [26]. Other authors did not give a strict definition and did not clarify how or why cases were included or excluded from their studies. Again, there was generally no explanation for choice of participants' ages, time elapsed from the SSNHL onset, or preceding events. Lack of clear eligibility criteria and relying solely on audiometric description of pediatric SSNHL introduce uncertainty, especially if specific conditions such as non-organic hearing loss, multiple sclerosis, auditory neuropathy, or central processing disorders (which, in fact, are not acute, but progressive entities) are excluded from analysis.

\section{SSNHL etiology}

Table 3 shows that only 7 of 13 articles provided data on possible pediatric SSNHL etiology. Discrepancies in formulation of definitions, eligibility criteria, and diagnostic protocols across the articles resulted in large inconsistencies in specific etiologies and their prevalence (e.g. a difference of greater than $70 \%$ in the prevalence of idiopathic SSNHL). Due to differences in methodology, diverse etiologies were identified and the prevalence of identified SSNHL causes was also discrepant. Although the most commonly reported etiology in children was idiopathic SSNHL, as in adult cases [1], other causative factors differed significantly.

\section{Hearing loss and classification of audiogram curve type}

Classifications of both hearing level and audiogram curve type were available in two studies $[15,26]$. The degree of hearing loss alone was provided in four articles $[18,21,23,27]$, and the category of audiogram curve was exclusively studied in four articles $[16,17,19,20]$. The main audiometric curve types were "ascending" (also called rising), when the average loss at 0.25 and $0.5 \mathrm{kHz}$ was $20 \mathrm{~dB}$ higher than the average loss at 4 and $8 \mathrm{kHz}$; "descending" (also called downward), when the average loss at 4 and 8 $\mathrm{kHz}$ was $20 \mathrm{~dB}$ higher than the average loss at 0.25 and $0.5 \mathrm{kHz}$; and "flat", when the difference in hearing loss did not exceed $20 \mathrm{~dB}$ between any frequencies.

Regarding the degree of hearing loss and classification, only Li et al. [26] used the generally accepted Grades of 
Table 3. The possible etiologies of SSNHL. Numbers in brackets show number of children (or affected number of ears) and percent. The order of the table is in year of publication

\begin{tabular}{|c|c|}
\hline Author & Possible pediatric SSNHL etiology (number of children/percent) \\
\hline Psarommatis et al. & $\begin{array}{l}\text { non-organic }(26 / 57 \%) \\
\text { idiopathic }(16 / 35 \%) \\
\text { large vestibular aqueduct syndrome }(2 / 4 \%) \\
\text { acoustic trauma }(2 / 4 \%) \\
\text { multiple sclerosis }(1 / 2 \%) \\
\text { herpes virus infection }(1 / 2 \%)\end{array}$ \\
\hline Tarshish et al. & $\begin{array}{l}\text { viral infection of unknown type }(12 / 60 \%) \\
\text { unknown }(2 / 17 \%) \\
\text { late presentation of congenital cytomegalic virus }(1 / 8 \%) \\
\text { noise-related }(1 / 8 \%) \\
\text { non-organic }(1 / 8 \%) \\
\text { large vestibular aqueduct syndrome }(1 / 8 \%) \\
\text { Epstein-Barr virus infection }(1 / 8 \%) \\
\text { ototoxic exposure }(1 / 8 \%) \\
\text { inflammatory cerebrovascular incident }(1 / 8 \%)\end{array}$ \\
\hline Jecmenica et al. & $\begin{array}{l}\text { meningitis }(17 / 29 \%) \\
\text { psychogenic }(14 / 24 \%) \\
\text { ototoxic drugs }(9 / 15 \%) \\
\text { idiopathic }(4 / 7 \%) \\
\text { parotitis }(3 / 5 \%) \\
\text { acoustic trauma }(2 / 3 \%) \\
\text { large vestibular aqueduct syndrome }(2 / 3 \%) \\
\text { Mondini dysplasia }(2 / 3 \%) \\
\text { cytomegalic virus }(2 / 3 \%) \\
\text { common cavity syndrome }(1 / 2 \%) \\
\text { palsy of facial nerve }(1 / 2 \%) \\
\text { fracture of temporal bone }(1 / 2 \%) \\
\text { iatrogenic trauma }(1 / 2 \%)\end{array}$ \\
\hline Pitaro et al. & $\begin{array}{l}\text { idiopathic ( } 14 / 74 \%) \\
\text { others (not specified) (5/26\%) }\end{array}$ \\
\hline Dedhia and Chi & $\begin{array}{l}\text { unknown }(6 / 30 \%) \\
\text { viral }(6 / 30 \%) \\
\text { large vestibular aqueduct syndrome }(4 / 20 \%) \\
\text { absent/hypoplastic cochlear nerve }(1 / 5 \%) \\
\text { Meniere's disease }(1 / 5 \%) \\
\text { autoimmune }(1 / 5 \%) \\
\text { perilymphatic fistula }(1 / 5 \%)\end{array}$ \\
\hline Li et al. & $\begin{array}{l}\text { no obvious factor (95 ears/63\%) } \\
\text { epidemic mumps (13 ears/9\%) } \\
\text { upper respiratory infection ( } 29 \text { ears/19\%) } \\
\text { fatigue ( } 6 \text { ears/4\%) } \\
\text { traumatic injury ( } 5 \text { ears/3\%) } \\
\text { others ( } 3 \text { ears/ } 2 \% \text { ) }\end{array}$ \\
\hline Kizilay and Koca & $\begin{array}{l}\text { idiopathic }(11 / 79 \%) \\
\text { mumps }(3 / 21 \%)\end{array}$ \\
\hline
\end{tabular}

Hearing Impairment from WHO [26]. Other authors used different audiometric criteria, probably based on their own experience. Audiometric frequencies chosen for assessing pure-tone average for pre- and post-treatment periods were also diverse. It was especially puzzling when authors mentioned an ascending or descending audiogram curve type, with the biggest hearing loss at perhaps low $(0.25-0.5 \mathrm{kHz})$ or high frequencies $(4-8 \mathrm{kHz})$, and yet used in their posttreatment evaluation a pure-tone average based only on medium frequencies (i.e. $0.5,1,2$, or $3 \mathrm{kHz}$ ). Categories of hearing recovery used to measure treatment outcomes also diverged in all reviewed studies. Such an approach creates a huge difficulty in comparing results.

\section{Treatment types}

The most common treatment was steroids, used in 11 of the 13 articles studied. There were three ways of administration: oral, intratympanic (IT), and intravenous. Hyperbaric oxygen therapy (HBOT) was used in three studies $[17,22,26]$, in each case complementary to the drug therapy. However, a detailed description of the treatment protocol was given only in the study of Narożny et al. [22]. The authors qualified children for the therapy according to the European Committee for Hyperbaric Medicine Guidelines (indication type 2). The number of HBOT sessions ranged from 1 to 30 (median 15). Data on how treatment regimen or medication dose was chosen were not provided in many articles. There were studies in which even the name, dose, or administration protocol of a drug were not given. The approach to diverse treatment regimens 
Table 4. Outcomes of pediatric SSNHL treatment based on pre- and post-treatment PTA measurements. Order of the table is in year of publication

\begin{tabular}{|c|c|c|c|c|}
\hline Author & Hearing recovery category & $\begin{array}{l}\text { Number } \\
\text { of children }\end{array}$ & $\begin{array}{l}\text { Number } \\
\text { of ears }\end{array}$ & Percent \\
\hline \multirow{3}{*}{ Roman et al.* } & Total hearing recovery & NP & 4 & $28.5 \%$ \\
\hline & Partial hearing recovery & NP & 4 & $28.5 \%$ \\
\hline & Absence of recovery & NP & 6 & $43 \%$ \\
\hline \multirow{3}{*}{ Chen et al.* } & Complete hearing recovery & 8 & 8 & $57 \%$ \\
\hline & Partial hearing recovery & 5 & 5 & $36 \%$ \\
\hline & Absence of recovery & 1 & 1 & $7 \%$ \\
\hline \multirow{3}{*}{ Narożny et al. } & $\begin{array}{l}\text { Hearing returned to normal or significant hearing } \\
\text { recovery }\end{array}$ & 7 & NP & $41 \%$ \\
\hline & Hearing recovery & 5 & NP & $29.5 \%$ \\
\hline & Absence of recovery & 5 & NP & $29.5 \%$ \\
\hline \multirow{4}{*}{ Inci et al.* } & Complete recovery & NP & 8 & $16 \%$ \\
\hline & Significant recovery & NP & 10 & $20 \%$ \\
\hline & Mild recovery & NP & 9 & $18 \%$ \\
\hline & No recovery & NP & 23 & $46 \%$ \\
\hline \multirow{4}{*}{ Na et al.* } & Complete recovery & 47 & NP & $54 \%$ \\
\hline & Partial recovery & 4 & NP & $4.6 \%$ \\
\hline & Slight improvement & 19 & NP & $21.8 \%$ \\
\hline & No improvement & 17 & NP & $19.6 \%$ \\
\hline \multirow{2}{*}{$\begin{array}{l}\text { Jecmenica and } \\
\text { Bajec-Opancina }\end{array}$} & With recovery & 48 & & $81 \%$ \\
\hline & Without recovery & 11 & & $23 \%$ \\
\hline \multirow{4}{*}{ Chung et al.* } & Complete recovery & 18 & NP & $46.6 \%$ \\
\hline & Partial recovery & 4 & NP & $10.8 \%$ \\
\hline & Slight recovery & 5 & NP & $13.5 \%$ \\
\hline & No recovery & 10 & NP & $27 \%$ \\
\hline \multirow{3}{*}{ Pitaro et al. } & Complete improvement of hearing & 3 & NP & $16 \%$ \\
\hline & Partial hearing recovery & 9 & NP & $47 \%$ \\
\hline & No improvement & 6 & NP & $37 \%$ \\
\hline \multirow{4}{*}{ Li et al. } & Complete hearing recovery & NP & 14 & $9.3 \%$ \\
\hline & Partial recovery & NP & 15 & $9.9 \%$ \\
\hline & Slight recovery & NP & 28 & $18.5 \%$ \\
\hline & No recovery & NP & 94 & $62.5 \%$ \\
\hline \multirow{3}{*}{ Kizilay and Koca } & Complete recovery & 3 & NP & $21.5 \%$ \\
\hline & Partial recovery & 0 & NP & $0 \%$ \\
\hline & Unchanged hearing loss & 11 & NP & $78.5 \%$ \\
\hline
\end{tabular}

NP - data not provided; * - only ISSNHL cases included.

๑๔ Journal of Hearing Science ${ }^{\circledR} \cdot 2016$ Vol. 6 ・ No. 4 
Table 5. Positive and negative prognostic factors in pediatric SSNHL recovery. Table is in order of publication year

\begin{tabular}{|c|c|c|}
\hline Author & Positive prognostic factors & Negative prognostic factors \\
\hline Roman et al. & $\begin{array}{l}\text { - Mild or moderate HL } \\
\text { - Tinnitus on SSNHL onset }\end{array}$ & $\begin{array}{l}\text { - Severe hearing loss } \\
\text { - Downward audiometric curve }\end{array}$ \\
\hline Inci et al. & & $\begin{array}{l}\text { - Vertigo at initial presentation } \\
\text { - Delayed treatment onset }\end{array}$ \\
\hline Na et al. & - Mild HL & - Severity of hearing loss (the more severe the worse) \\
\hline Chung et al. & $\begin{array}{l}\text { Univariate analysis } \\
\text { - Early treatment onset } \\
\text { - Tinnitus on SSNHL onset } \\
\text { Multivariate analysis } \\
\text { - Tinnitus on SSNHL onset } \\
\text { - Early treatment } \\
\text { - Initial audiometric threshold (the lower the better) }\end{array}$ & \\
\hline Li et al. & $\begin{array}{l}\text { Univariate analysis } \\
\text { - Unilateral HL } \\
\text { - Early onset of treatment } \\
\text { - Initial degree of hearing loss (the milder the better) } \\
\text { - Ascending audiogram } \\
\text { - Present ABR waves and DPOAEs } \\
\text { Multivariate analysis } \\
\text { - Tinnitus on SSNHL onset } \\
\text { - Early treatment } \\
\text { - Female gender }\end{array}$ & $\begin{array}{l}\text { Multivariate analysis } \\
\text { - Bilateral hearing loss } \\
\text { - Severe-profound hearing loss }\end{array}$ \\
\hline
\end{tabular}

differed between authors. Dedhia and Chi [27] presented a skeptical approach towards HBOT in children. However, Narożny et al. [22] published results suggesting there was a beneficial effect of this complementary therapy. HBOT was also used in two different studies conducted by Inci et al. [17] and Li et al. [26], but the authors did not refer to its separate usefulness or positive or negative effects.

Treatment effectiveness measurement methods and outcomes

All authors evaluated treatment outcomes based on puretone averages, although different frequencies were evaluated. The methods used to measure treatment effectiveness also differed significantly between studies. Roman et al. [19] distinguished 3 types of hearing recovery: "total hearing recovery" (hearing recovery of 90-100\%), "partial hearing recovery" (11-89\%), and "absence of recovery" (0-10\%). Chen et al. [20] described "complete hearing recovery" as the same hearing level as in the non-affected ear, and "partial hearing recovery" as recovery of at least $10 \mathrm{~dB}$ at three frequencies. Narożny et al. [22] speak of "hearing returned to normal level", "significant hearing recovery" (hearing recovery $>25 \mathrm{~dB}$ ), "hearing recovery" $(10-25 \mathrm{~dB})$, and "lack of hearing recovery" ( $<10 \mathrm{~dB})$. Inci et al. [17] divided hearing recovery into "complete recovery" when hearing thresholds changed less than $20 \mathrm{~dB}$ at all frequencies, "significant recovery" when average hearing threshold gain was more than $30 \mathrm{~dB}$, "mild recovery" when average hearing threshold improved by 11-29 dB, and "no recovery" when gain in average hearing threshold was 0-10 dB. Jecmenica and Bajec-Opancina [24] differentiated two categories of patient: those with and without recovery, but data on audiological or other classifications used to assign patients to one or other of the groups was not provided. Na et al. [15] reported four types of hearing recovery: "complete recovery", "partial recovery", "slight improvement", and "no improvement". Patients from the first three types were classified as "recovered", but no further audiological criteria were given. Chung et al. [16] described "complete recovery" as final hearing level less than 25 dB HL; "partial recovery" as final hearing level from 25 to $45 \mathrm{~dB}$ HL; "slight recovery" as final hearing over 45 $\mathrm{dB}$ HL with hearing gain of $\geq 15 \mathrm{~dB}$; and "no recovery" as final hearing level over $75 \mathrm{~dB}$ HL with hearing gain of $\leq 15 \mathrm{~dB}$. In the study, complete recovery plus partial recovery were considered as "recovery", whereas slight recovery and no improvement were classified as "no recovery". Pitaro et al. [25] defined "complete improvement of hearing" as a hearing level the same as in the non-affected ear, "partial hearing recovery" as an improvement of more than $10 \mathrm{~dB}$ at one or more frequencies, and "no improvement" when there was no change in the audiogram following treatment. According to Li at al. [26], "complete hearing recovery" was a pure-tone average improvement of less than <25 dB; "partial recovery" was an improvement of over $30 \mathrm{~dB}$; "slight recovery" an improvement of 15-30 $\mathrm{dB}$; and "no recovery" meant hearing recovery of less than $15 \mathrm{~dB}$ at the final follow-up. Overall recovery rates were calculated based on patients from the complete, partial, and slight recovery groups. Kizilay and Koca [18] divided patients into "complete recovery" (same hearing lev$\mathrm{el}$ as in the non-affected ear), "partial recovery", and "unchanged hearing loss". Psarommatis et al. [21] provided no information on treatment effectiveness or outcomes of hearing recovery. Tarshish et al. [23] did not include a description of hearing recovery; however, changes in the PTA for the right and left ear separately were presented in tabular form. Dedhia and Chi [27] claimed to achieve "improvement" in 4 of 8 patients treated with steroids, but no data on hearing recovery was provided. As a summary, the outcomes of pediatric SSNHL treatment based on pre- and post-treatment PTA measurements according to different authors are presented in Table 4. Considering the 
proposed criteria, overall total/complete recovery ranged from 9 to $57 \%$. On the other hand, absence of recovery was noted in $7-78 \%$ of cases.

\section{Treatment complications}

Only 4 of 13 articles provided information about treatment complications, and all 4 were attributed to steroid administration. Based on their results, no serious adverse events were seen in the pediatric population in general. Further, it was stated that even if a complication did occur, it was linked to the specific condition of the patient or subsided after modification of the treatment protocol or termination of therapy.

\section{Follow-up schedules and prognostic factors}

Follow-up schedules together with follow-up time were poorly described and differed significantly between studies, so it is not clear if treatment regimens were sufficient to maintain therapeutic effects over an extended period. Table 5 shows the positive and negative prognostic factors for hearing recovery in pediatric SSNHL identified in the literature. The substantial differences in diagnostic and treatment protocols used by different authors could have created discrepancies in identified prognostic factors. Actually, the only consistent factor between authors was the degree of hearing loss, with all concluding that the milder the degree of hearing loss, the better was the prognosis for hearing recovery.

\section{Conclusions}

As long as 10 years ago clinicians dealing with pediatric SSNHL emphasized the need for prospective, placebo-controlled trials on different types of treatment for children. The absence of data on spontaneous recovery in this group of patients was also emphasized [20], supporting the need to develop better disease-focused management protocols. The majority of authors are in agreement that improperly diagnosed and treated pediatric SSNHL may have a negative impact on children's language and psychological development $[15,18,23,25,26]$. Lack of standardization of approaches to the diagnosis and management of SSNHL leaves children without appropriate health care. As evident from this literature review, current data concerning pediatric SSNHL is inconsistent and sometimes mutually exclusive. For the sake of improving auditory science, the definition of sudden sensorineural hearing loss, sudden deafness, acute hearing loss, and sudden sensorineural hearing loss should be clarified and specified. Prospective longitudinal studies - with strict eligibility criteria, clear methodology, and thorough diagnostic and treatment protocols - are needed in order to provide evidence-based, reliable knowledge on which future guidelines on pediatric SSNHL can be based.

\section{Conflict of interest}

None.

\section{Funding}

This research did not receive any specific grant from funding agencies in the public, commercial, or not-for-profit sectors.

\section{References:}

1. Stachler RJ, Chandrasekhar SS, Archer SM, Rosenfeld RM, Schwartz SR, Barrs DM et al. Clinical practice guideline: Sudden hearing loss. Otolaryngol Head Neck Surg, 2012;146: 1-35.

2. Theunissen SC, Rieffe C, Netten AP, Briaire JJ, Soede W, Kouwenberg $M$ et al. Self-esteem in hearing-impaired children: The influence of communication, education, and audiological characteristics. PLoS One, 2014; 9: e94521.

3. Theunissen SC, Rieffe C, Kouwenberg M, De Raeve LJ, Soede $\mathrm{W}$, Briaire JJ et al. Behavioral problems in school-aged hearing-impaired children: The influence of sociodemographic, linguistic, and medical factors. Eur Child Adolesc Psychiatry, 2014; 23: 187-96.

4. Kobosko J. [Mental health problems of the deaf, hard of hearing and hearing children from the general population in their parents' reports]. Now Audiofonol, 2012; 1: 56-66 [in Polish].

5. Theunissen SCPM, Rieffe C, Kouwenberg M, Soede W, Briaire JJ, Frijns JHM. Depression in hearing-impaired children. Int J Pediatr Otorhinolaryngol, 2011;75: 1313-17.

6. Fellinger J, Holzinger D, Sattel H, Laucht M, Goldberg D. Correlates of mental health disorders among children with hearing impairments. Dev Med Child Neurol, 2009; 51: 635-41.

7. Walker R. Child mental health and deafness. Paediatr Child Health, 2013;23: 438-42.
8. Kuhn M, Heman-Ackah SE, Shaikh JA, Roehm PC. Sudden sensorineural hearing loss: A review of diagnosis, treatment, and prognosis. Trends Amplif, 2011;15: 91-105.

9. Śliwińska M. Kryteria oceny słyszenia u osób wykonujących pracę wymagającą dobrej sprawności słuchu. Otorynolaryngologia, 2013; 12(3): 105-11 [in Polish].

10. Buda K, Daroszewska M, Ciesielska N, Sokołowski R, Ferenc S, Sysakiewicz M et al. The guidelines of the European Society of Hyperbaric Medicine, the Society of Underwater and Hyperbaric Medicine and the National Health Fund Polish Republic on a hyberbaric oxygen therapy (HBOT) in 2013. J Health Sci, 2013; 3(9): 125-34.

11. Plaza G, Durio E, Herráiz C, Rivera T, García-Berrocal JR. Consensus on diagnosis and treatment of sudden hearing loss. Acta Otorrinolaringol Esp (Engl Ed), 2011; 62: 144-57.

12. Kenna MA. Acquired hearing loss in children. Otolaryngol Clin North Am, 2015; 48: 933-53.

13. Nissen T, Wynn R. The clinical case report: A review of its merits and limitations. BMC Res Notes, 2014;7: 264.

14. Convention on the Rights of the Child [Internet]. Downloaded 2016 Sep 19, available from: http://www.ohchr.org/en/professionalinterest/pages/crc.aspx.

15. Na SY, Kim MG, Hong SM, Chung JH, Kang HM, Yeo SG. Comparison of sudden deafness in adults and children. Clin Exp Otorhinolaryngol, 2014;7: 165-69. 
16. Chung JH, Cho SH, Jeong JH, Park CW, Lee SH. Multivariate analysis of prognostic factors for idiopathic sudden sensorineural hearing loss in children. Laryngoscope, 2015;125: 2209-15.

17. Inci E, Edizer DT, Tahamiler R et al. Prognostic factors of sudden sensorineural hearing loss in children. J Int Adv Otol, 2011;7: 62-6.

18. Kizilay A, Koca ÇF. Pediatric sudden sensorineural hearing loss. J Craniofac Surg, 2016;27: 364-66.

19. Roman S, Aladio P, Paris J, Nicollas R, Triglia JM. Prognostic factors of sudden hearing loss in children. Int J Pediatr Otorhinolaryngol, 2001;61: 17-21.

20. Chen Y-S, Emmerling O, Ilgner J, Westhofen M. Idiopathic sudden sensorineural hearing loss in children. Int J Pediatr Otorhinolaryngol, 2005;69: 817-21.

21. Psarommatis I, Ioannis P, Kontorinis G, et al. Pseudohypacusis: The most frequent etiology of sudden hearing loss in children. Eur Arch Otorhinolaryngol, 2009; 266: 1857-61.

22. Narożny W, Kot J, Kuczkowski J, Sićko Z, Stankiewicz C. Hiperbaria tlenowa u dzieci z nagłym niedosłuchem czuciowonerwowym. Otolaryngologia, 2010;9(1): 30-35 [in Polish].
23. Tarshish Y, Leschinski A, Kenna M. Pediatric sudden sensorineural hearing loss: Diagnosed causes and response to intervention. Int J Pediatr Otorhinolaryngol, 2013; 77: 553-59.

24. Ječmenica J, Bajec-Opančina A. Sudden hearing loss in children. Clin Pediatr (Phila), 2014;53(9): 874-78.

25. Pitaro J, Bechor-Fellner A, Gavriel H, Marom T, Eviatar E. Sudden sensorineural hearing loss in children: Etiology, management, and outcome. Int J Pediatr Otorhinolaryngol, 2016;82: 34-37.

26. Li FJ, Wang DY, Wang HY, Wang L, Yang FB, Lan L et al. Clinical study on 136 children with sudden sensorineural hearing loss. Chin Med J (Engl), 2016; 129: 946-52.

27. Dedhia K, Chi DH. Pediatric sudden sensorineural hearing loss: Etiology, diagnosis and treatment in 20 children. Int J Pediatr Otorhinolaryngol, 2016; 88: 208-12.

28. Alexander TH, Harris JP. Incidence of sudden sensorineural hearing loss. Otol Neurotol, 2013; 34: 1586-89.

29. Lee JS, Hong SK, Kim DH, Lee JH, Lee HJ, Park B et al. The neutrophil-to-lymphocyte ratio in children with sudden sensorineural hearing loss: A retrospective study. Acta Otolaryngol (Stockh), 2017; 137(1): 35-38. 